Lovas Gábor

(szerk.)

\section{VAN MEGOLDÁS}

\section{0 éves a \\ Munkaügyi Közvetítói és Döntőbírói Szolgálat}

MKDSZ és MGYOSZ, 2007

A nálunk most már tíz éve mứködó Munkaiigyi Közvetítői és Döntőbírói Szolgálatról (MKDSZ) és annak érdemi tevékenységéről ad nagyon érdekes és tanulságos áttekintést ez a kötet.

A modern társadalomnak és az annak anyagi alapjait adó gazdaságnak egyik meghatározó jellemzớje, hogy mindkettó a különbözó érdekcsoportok harctere. Ennek egyik különösen fontos területe a munkaadók és a munkavállalók viszonya. Ebben döntő́ jelentôségũ, hogy a munkával megtermelt értéktöbblet kettejük között történő felosztása zérooösszegú játszma, azaz az egyik fél részarányának emelése csak a másikéból történhet. Ez tehát ebben a vonatkozásban szükségképpen szembeállítja a munkaadókat és a munkavállalókat. A modem társadalom a jogrend révén igyekszik olyan kereteket létrehozni, mindkét felet kötó szabályés intézményrendszert múködtetni, amelyek segítenek a munkaadók és a munkavállalók közötti konfliktusok megoldásában, és fớként azoknak a hatásoknak a tompításában, amelyek zavarhatják a társadalom és/vagy a nemzetgazdaság múködését. Tudjuk, tapasztaljuk, hogy a munkaadóikkal szembeni érdekérvényesítésben a munkavállalók végsó́ eszköze a sztrájk. A klaszszikus idókben annak alapvetó rendeltetése az volt, hogy megfossza az elóbbieket a munka hozamától. A társadalom számára fóként azzal válik zavaróvá, ha olyan szolgálta- tásokat állít le, amelyekre sokaknak szükségük van, a sztrájkolók pedig éppen ezt használják eszközül arra, hogy kikényszerítsék céljuk elérését. Ezért társadalmi érdek, hogy ne fajuljanak idáig a konfliktusok, vagy minél rövidebb ideig tartsanak. Ugyanakkor az ilyen viták bírósági úton történó rendezése a hatásaiktól szenvedő érintettek számára elfogadhatatlan mértékben is elhúzódhat. Ezért az ezt szolgáló intézményrendszer különösen fontos elemei a fejlett országokban a munkaügyi közvetítói és döntőbírói szolgálatok.

Ez nem elméleti munka, hanem nagyon gyakorlatias tájékoztatás. A legfontosabb, amit megtudhatunk belóle a Szolgálatról, nem is maga a léte - arról az érdekeltek tudnak, vagy szükség esetén tudomást szereznek -, hanem múködésének módja és az eredményei. Minden érdekütközés megoldásának a leghatékonyabb módja egy olyan megállapodás létrehozása, amelyet a szembenálló felek mindegyike úgy ítél meg, hogy nyert vele. Csak ez teremthet esélyt arra, hogy képesek lesznek jól együttmúködni. Az ilyen megoldások kimunkálásához és elfogadtatásához pedig nagyon komoly szakmai felkészültség és többféle képesség is kell a helyzetelemzéstól a szembenálló felek meggyőzéséig. Amint a bevezetớben olvashatjuk, az MKDSZ 1996 óta nyújt szolgáltatást a munkaügyi kapcsolatok szereplói számára. Tevékenységének jogi alapját ma már sui generis („testreszabott”) jogszabálya, a közvetítói tevékenységról szóló 2002. évi LV. törvény adja. Eredményességét jellemzi, hogy a sikerrel zárult közvetítéseinek részaránya az eddigi teljes múködését tekintve meghaladta a $95 \%$-ot. Ehhez persze az kell, hogy a szemben álló felek megegyezzenek a közvetítóként való bekapcsolásában, ahhoz pedig az, hogy ismerjék ennek célszerúségét. Ebben is segíthet ez a kiadvány. Benne négy konkrét ügynek a lényeget kiemeló bemutatását találjuk, s mindegyikhez részletes jogi szakkommentárt, továbbá elemzést arról is, hogyan válhat valaki közvetítóvé, milyen a jó közvetítő és milyen szabályok kötik. Közli az MKDSZ teljes Szervezeti, Mnködési és Eljárási Szabályzatát is, amely szintén sok érdemi információval szolgál az érdeklődóknek, valamint a mediátorok névsorát, azok érdemi, szakmai bemutatásával. Utóbbiakban különösen érdekes látnunk, milyen sokféle szakmai elóélettel, hányféle területról jöttek - ami nyilvánvalóan sokat segíthet abban, hogy az MKDSZ az ügyekhez az azok környezetét jól ismeró közvetítőt válasszon.

(Osman Péter)

\section{AZ EZREDFORDULÓ VILÁGGAZDASÁGA - A VILÁGGAZDASÁG EZREDFORDULÓJA}

\section{Recenzió Blahó András és munkaközössége: Világgazdaságtan címú múvéről}

(Akadémiai Kiadó, Budapest, 2007, 368 oldal)

A világgazdaság folyamataival foglalkozó, hagyományos megközelítésú tankönyvek, amelyek magukat elnevezésükben is megkülönböztetik: nemzetközi gazdaságtan vagy nemzetközi közgazdaságtan -, tárgyukat mint a nemzetek (helyesebb lenne: országok) közötti kapcsolatokat, áramlásokat és viszonyokat közelítik meg, és mellózik a történetiséget, valamint a globális összefüggések vizsgálatát. Sikerül is így egy modellekre épülö, matematikai 